\title{
Jean-Louis Debauve, Autour du cent-cinquantième anniversaire des Fleurs du mal
}

\section{Ida Merello}

\section{(2) OpenEdition}

1 Journals

\section{Edizione digitale}

URL: http://journals.openedition.org/studifrancesi/8993

DOI: ERREUR PDO dans/localdata/www-bin/Core/Core/Db/Db.class.php L.34 : SQLSTATE[HYO00]

[2006] MySQL server has gone away

ISSN: 2421-5856

\section{Editore}

Rosenberg \& Sellier

\section{Edizione cartacea}

Data di pubblicazione: 1 octobre 2008

Paginazione: 481

ISSN: 0039-2944

\section{Notizia bibliografica digitale}

Ida Merello, «Jean-Louis Debauve, Autour du cent-cinquantième anniversaire des Fleurs du mal», Studi Francesi [Online], 155 (LII | II) | 2008, online dal 30 novembre 2015, consultato il 07 janvier 2021. URL: http://journals.openedition.org/studifrancesi/8993; DOI: https://doi.org/ERREUR PDO dans / localdata/www-bin/Core/Core/Db/Db.class.php L.34 : SQLSTATE[HY000] [2006] MySQL server has gone away

Questo documento è stato generato automaticamente il 7 janvier 2021.

\section{(c)}

Studi Francesi è distribuita con Licenza Creative Commons Attribuzione - Non commerciale - Non opere derivate 4.0 Internazionale. 


\title{
Jean-Louis Debauve, Autour du cent- cinquantième anniversaire des Fleurs du mal
}

\author{
Ida Merello
}

\section{NOTIZIA}

JEAN-LOUIS DEBAUVE, Autour du cent-cinquantième anniversaire des Fleurs du mal, «Histoires littéraires», n. 31, juill-août-sept. 2007, pp. 51-60.

1 L'A. presenta sette lettere, di cui una in precedenza solo parzialmente nota, tre appena menzionate fino ad oggi e tre comparse in cataloghi d'autografi piuttosto recenti. A queste aggiunge una lettera del generale Aupick dove è citato il figlio Charles e un documento, proveniente da un fondo di Poulet-Malassis, in cui l'editore riporta una conversazione tra Baudelaire e Sainte-Beuve. 